University of Nebraska - Lincoln

DigitalCommons@University of Nebraska - Lincoln

2012

\title{
Reducing odorous VOC emissions from swine manure using soybean peroxidase and peroxides
}

\author{
David B. Parker \\ West Texas A\&M University, david.parker@ars.usda.gov \\ Lingshuang Cai \\ USDA-ARS, U.S. Meat Animal Research Center
}

Ki-Hyun Kim

Sejong University, khkim@sejong.ac.kr

Kristin E. Hales

USDA-ARS, U.S. Meat Animal Research Center, kristin.hales@ars.usda.gov

Mindy J. Spiehs

USDA-ARS, U.S. Meat Animal Research Center, mindy.spiehs@ars.usda.gov

See next page for additional authors

Follow this and additional works at: https://digitalcommons.unl.edu/bioscifacpub

Part of the Life Sciences Commons

Parker, David B.; Cai, Lingshuang; Kim, Ki-Hyun; Hales, Kristin E.; Spiehs, Mindy J.; Woodbury, Bryan L.; Atkin, Audrey L.; Nickerson, Kenneth; and Patefield, Krista D., "Reducing odorous VOC emissions from swine manure using soybean peroxidase and peroxides" (2012). Faculty Publications in the Biological Sciences. 233.

https://digitalcommons.unl.edu/bioscifacpub/233

This Article is brought to you for free and open access by the Papers in the Biological Sciences at DigitalCommons@University of Nebraska - Lincoln. It has been accepted for inclusion in Faculty Publications in the Biological Sciences by an authorized administrator of DigitalCommons@University of Nebraska - Lincoln. 


\section{Authors}

David B. Parker, Lingshuang Cai, Ki-Hyun Kim, Kristin E. Hales, Mindy J. Spiehs, Bryan L. Woodbury, Audrey L. Atkin, Kenneth Nickerson, and Krista D. Patefield 


\title{
Reducing odorous VOC emissions from swine manure using soybean peroxidase and peroxides
}

\author{
David B. Parker ${ }^{\mathrm{a}, \mathrm{b}, *}$, Lingshuang Cai ${ }^{\mathrm{b}}$, Ki-Hyun Kim ${ }^{\mathrm{c}}$, Kristin E. Hales ${ }^{\mathrm{b}}$, Mindy J. Spiehs ${ }^{\mathrm{b}}$, \\ Bryan L. Woodbury ${ }^{b}$, Audrey L. Atkin ${ }^{d}$, Kenneth W. Nickerson ${ }^{d}$, Krista D. Patefield ${ }^{d}$ \\ a Palo Duro Research Center, West Texas AEM University, Canyon, TX 79016, United States \\ ${ }^{\mathrm{b}}$ USDA-ARS, U.S. Meat Animal Research Center, Clay Center, NE 68933, United States \\ ' Department of Environment E' Energy, Sejong University, Seoul 143-747, Republic of Korea \\ ${ }^{\mathrm{d}}$ School of Biological Sciences, University of Nebraska-Lincoln, NE 68588, United States
}

\section{H I G H L I G H T S}

- Soybean peroxidase and peroxides were applied to swine manure for odor control.

- The optimum industrial-grade soybean peroxidase rate was $50 \mathrm{~g} \mathrm{~L}^{-1}$.

- Calcium peroxide was more effective than hydrogen peroxide.

- The primary odorant 4-methylphenol accounted for $68-81 \%$ of the odor activity value.

- A 4-methylphenol reduction of $92 \%$ was achieved.

\section{A R T I C L E I N F O}

\section{Article history:}

Received 25 June 2012

Received in revised form 6 August 2012

Accepted 9 August 2012

Available online 17 August 2012

\section{Keywords:}

Odor

Swine

Volatile organic compound

Gas chromatography

Manure

\begin{abstract}
A B S T R A C T
The objective of the research was to determine the optimum application rates of soybean peroxidase (SBP) plus peroxide (SBPP) for reducing odorous VOC emissions from swine manure. Industrial-grade SBP was applied in combination with liquid hydrogen peroxide $\left(\mathrm{H}_{2} \mathrm{O}_{2}\right)$ or powdered calcium peroxide $\left(\mathrm{CaO}_{2}\right)$ to standard phenolic solutions and swine manure, and emissions were measured in a wind tunnel. The primary odorant in the untreated manure was 4-methylphenol, which accounted for $68-81 \%$ of the odor activity value. At the optimum application rate of SBPP $\left(50 \mathrm{~g} \mathrm{~L}^{-1}\right), 4$-methylphenol emissions were reduced from the swine manure by $62 \%\left(\mathrm{H}_{2} \mathrm{O}_{2}\right)$ and $98 \%\left(\mathrm{CaO}_{2}\right)$ after $24 \mathrm{~h}(P<0.0001)$. The $\mathrm{CaO}_{2}$ had a longer residence time, remaining effective for $48 \mathrm{~h}$ with $92 \%$ reduction in emission rates $(P<0.0001)$, while $\mathrm{H}_{2} \mathrm{O}_{2}$ was similar to the control at $48 \mathrm{~h}(P=0.28)$.
\end{abstract}

(ㄷ) 2012 Elsevier Ltd. All rights reserved.

\section{Introduction}

Volatile organic compounds (VOC) are emitted from wastewater treatment plants, food processing plants, landfills, and animal feeding operations (Kim et al., 2006). Volatile organic compound emissions are an important aspect of air quality because many are malodorous. There has been a growing concern in recent years over VOC emissions and the related nuisances from agricultural

Abbreviations: SBP, soybean peroxidase; SBPP, soybean peroxidase plus peroxide; HRP, horseradish peroxidase; VFA, volatile fatty acid; VOC, volatile organic compound; TD, thermal desorption; GC, gas chromatography; MS, mass spectrometry; DM, dry matter; OAV, odor activity value.

* Corresponding author at: Palo Duro Research Center, West Texas A\&M University, Canyon, TX 79015, United States. Tel.: +1 8066514099.

E-mail address: dparker@wtamu.edu (D.B. Parker). operations, prompting several states to enact ambient odor regulations (Sweeten, 1995; Chen et al., 1999; CAQCC, 1999; Redwine and Lacey, 2000).

More than 200 VOC have been identified in air emissions from manure and animal feeding operations (Kai and Schafer, 2004; Akdeniz et al., 2010). These VOC originate from the degradation of amino acids in the intestines of animals and anaerobic decomposition of manure (Mata-Alvarez et al., 2000; Kai and Schafer, 2004; Chen et al., 2008). Ammonia, volatile fatty acids (VFA), sulfides, 4-methylphenol (i.e. $p$-cresol), phenol, indole, and skatole are among the most commonly reported odorants associated with animal manures (Mackie et al., 1998). Many odorous compounds are emitted at animal feeding operations, but it is the phenolic and indolic compounds that dominate the overall odor at distance from these operations (Parker, 2007). As such, these compounds are the 
logical target for reduction of specific odorous VOCs in areas affected by animal feeding activities.

Peroxidase enzymes have been investigated for use in the abatement of phenolic contaminants in wastewaters (Morawski et al., 2001). In the presence of peroxides such as hydrogen peroxide $\left(\mathrm{H}_{2} \mathrm{O}_{2}\right)$ or calcium peroxide $\left(\mathrm{CaO}_{2}\right)$, the peroxidase polymerizes some phenolic and indolic compounds, making them insoluble and non-volatile compounds and thereby reducing the odor (Tonegawa et al., 2003). There are many different kinds of peroxidase enzymes, but horseradish peroxidase (HRP) and soybean peroxidase (SBP) have been the most studied. HRP and SBP are naturally occurring enzymes isolated from plant roots and above ground biomass. The medicinal and enzymatic properties of HRP have been studied for more than two centuries (Veitch, 2004).

While there has been considerable research on peroxidase enzymes for treatment of wastewaters, only recently was the technology applied to treatment of manure for odor control. Govere et al. (2007) demonstrated the removal of phenolic compounds from swine manure using minced horseradish roots, while Ye et al. (2009) showed that purified HRP was efficient at reducing concentrations of phenol, 4-methylphenol, indole, and skatole in diethyl ether extracts taken from swine manure slurry. The primary drawback to using raw horseradish root is the limited supply, while the drawback of purified HRP is the excessive cost. The highest activity of SBP is found in the soybean hulls (i.e. the seed coat) of the plant (Gijzen et al., 1993). Soybean hulls are a relatively inexpensive byproduct of soybean processing for oil and meal production. Soybean peroxidase and particularly soybean hulls are more plentiful than HRP because soybeans are one of the most abundant crops produced in the world. The U.S. produced about 81 million metric tons of soybeans on 30 million hectares in 2007 (Masuda and Goldsmith, 2009). In contrast, only about 10,000 metric tons of horseradish are harvested from 2000 hectares in the U.S. annually (Bratsch, 2009).

The initial objectives of this research were to evaluate and optimize a commercially-available plant-derived SBP enzyme product for reducing odorous VOC emissions from swine manure. In order to optimize its application toward odor reduction, we further compared the efficacy of SBP in combination with one of two peroxide sources (liquid hydrogen peroxide and powdered calcium peroxide) in a method named SBPP for soybean peroxidase plus peroxide.

\section{Methods}

\subsection{Experimental design}

A total of 12 experiments were conducted, and the five experiments that best describe the treatment system are presented in this manuscript. The first two experiments employed standard solutions of phenol and 4-methylphenol while the last three employed actual slurries of swine manure (Table 1). Experiment 1 varied the concentration of SBP with a constant level of $\mathrm{H}_{2} \mathrm{O}_{2}$, while Experiment 2 varied the concentration of $\mathrm{H}_{2} \mathrm{O}_{2}$ with a constant level of SBP. In Experiments 3-5, treatments were applied to swine manure slurry. For all experiments, $200 \mathrm{~mL}$ of standard solution or swine manure slurry were placed in $500 \mathrm{~mL}$ glass beakers where the treatments were applied. Following addition of SBP and either $\mathrm{H}_{2} \mathrm{O}_{2}$ or $\mathrm{CaO}_{2}$, the components were thoroughly mixed. The mixtures were incubated in the beakers for $2-72 \mathrm{~h}$, and then $175 \mathrm{~mL}$ of the standard solution or $175 \mathrm{~g}$ of the manure solution was transferred to a $138 \mathrm{~mm}$ diameter Petri dish to measure VOC emissions in a small wind tunnel. Further details on individual experiments are provided below and in Table 1.

\subsubsection{Experiment 1}

Experiment 1 was conducted to evaluate the effect of varying SBP application rate when applied to a standard phenolic solution consisting of $1 \mathrm{mM}$ phenol and $1 \mathrm{mM}$ 4-methylphenol in distilled water. There was a control treatment (no additives) and SBP treatments of $0.1,0.5,1.0,2.5,5.0$ and $10.0 \mathrm{~g} \mathrm{~L}^{-1}$ each with $2.64 \mathrm{mM}$ $\mathrm{H}_{2} \mathrm{O}_{2}$. The SBP and $\mathrm{H}_{2} \mathrm{O}_{2}$ were thoroughly mixed in a glass beaker containing the phenolic standard solution and incubated at $21.0^{\circ} \mathrm{C}$. After $2 \mathrm{~h}$, the treated solutions were transferred to Petri dishes, and emissions of phenol and 4-methylphenol were measured in a small wind tunnel. For this experiment and the subsequent experiments, there was one Petri dish per treatment, and two sorbent tube VOC samples were collected on each Petri dish.

\subsubsection{Experiment 2}

Experiment 2 was conducted to evaluate the effect of varying $\mathrm{H}_{2} \mathrm{O}_{2}$ concentrations when applied to the same standard phenolic solution containing $1 \mathrm{mM}$ phenol and $1 \mathrm{mM}$ 4-methylphenol in distilled water. There was a control treatment (no additives) and $\mathrm{H}_{2} \mathrm{O}_{2}$ treatments of $0.4,1.3,2.6,5.3,10.6$, and $44.1 \mathrm{mM}$. Each $\mathrm{H}_{2} \mathrm{O}_{2}$ treatment also received $5 \mathrm{~g} \mathrm{~L}^{-1}$ SBP. Phenol and 4-methylphenol emissions were measured after $2 \mathrm{~h}$.

\subsubsection{Experiment 3}

Experiment 3 was conducted to optimize SBP concentrations when applied with $\mathrm{H}_{2} \mathrm{O}_{2}$ to swine manure slurry. There was a control treatment (no additives) and SBP dosages of 5, 25, 50, 75, and $100 \mathrm{~g} \mathrm{~L}^{-1}$. All SBP treatments were accompanied by $\mathrm{H}_{2} \mathrm{O}_{2}$ at concentrations of $14.6 \mathrm{mM}$. Volatile organic compound emissions were measured at times of $2,24,48$, and $72 \mathrm{~h}$ after treatment.

\subsubsection{Experiment 4}

Experiment 4 was conducted to optimize $\mathrm{H}_{2} \mathrm{O}_{2}$ or $\mathrm{CaO}_{2}$ concentrations when applied with SBP to swine manure. There were six manure treatments that all received the fixed amount of SBP at $50 \mathrm{~g} \mathrm{~L}^{-1}$, and a control treatment that received neither SBP nor peroxide. Two of the SBP treatments received $\mathrm{H}_{2} \mathrm{O}_{2}$ at concentrations of 14.6 and $38.0 \mathrm{mM}$. Four of the SBP treatments received $\mathrm{CaO}_{2}$ at concentrations of $14.6,22.1,38.0$, and $76.0 \mathrm{mM}$. Volatile organic compound emissions were measured at times of 2,24 , and $48 \mathrm{~h}$ after treatment.

Table 1

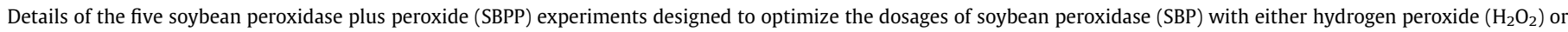
calcium peroxide $\left(\mathrm{CaO}_{2}\right)$.

\begin{tabular}{|c|c|c|c|c|c|c|}
\hline Experiment No. & Purpose & Source & Time evaluated $(\mathrm{h})$ & SBP added $(\mathrm{g} / \mathrm{L})$ & $\mathrm{H}_{2} \mathrm{O}_{2}(\mathrm{mM})$ & $\mathrm{CaO}_{2}(\mathrm{mM})$ \\
\hline 1 & Optimize SBP & Std. solution ${ }^{\mathrm{a}}$ & 2 & $0-10$ & 2.65 & 0 \\
\hline 2 & Optimize $\mathrm{H}_{2} \mathrm{O}_{2}$ & Std. solution & 2 & 5 & $0-44.1$ & 0 \\
\hline 3 & Optimize SBP & Swine manure & $2,24,48,72$ & $0-100$ & 14.6 & 0 \\
\hline 4 & Optimize $\mathrm{H}_{2} \mathrm{O}_{2}$ and $\mathrm{CaO}_{2}$ & Swine manure & $2,24,48$ & 50 & $0-38.0$ & $0-76.0$ \\
\hline 5 & Replicated experiment & Swine manure & $2,24,48$ & 50 & 14.6 & 22.1 \\
\hline
\end{tabular}

a Std. solution of $1 \mathrm{mM}$ phenol and $1 \mathrm{mM}$ 4-methylphenol. 


\subsubsection{Experiment 5}

A final replicated experiment was conducted to compare the most effective treatments from Experiments 3 and 4. The three treatments consisted of (1) a control with no amendments, (2) $14.6 \mathrm{mM} \mathrm{H}_{2} \mathrm{O}_{2}$ plus $50 \mathrm{~g} \mathrm{~L}^{-1} \mathrm{SBP}$, (3) $22.1 \mathrm{mM} \mathrm{CaO}_{2}$ plus $50 \mathrm{~m} \mathrm{~L}^{-1} \mathrm{SBP}$. There were three replicates of each treatment, and emissions were measured at times of 2, 24, and $48 \mathrm{~h}$ following application. In addition, $\mathrm{pH}$ of swine slurry was measured at times of $0,2,24$, and $48 \mathrm{~h}$.

\subsection{Reagents, soybean peroxidase, and swine manure}

The SBP used in this study was an industrial grade product (Cat. No. X516-IND; Bio-Research Products Inc., North Liberty, Iowa, USA) which had a tan-reddish fine powder with a nominal activity of $0.77 \mathrm{U} \mathrm{mg}^{-1}$ ( $\mathrm{U}=$ guaiacol activity units). Liquid hydrogen peroxide (30\%, ACS grade), powdered calcium peroxide $(20 \%$, ACS grade), and phenol and 4-methylphenol (>99\%, ACS grade) were obtained from Fisher Scientific (St. Louis, Missouri, USA).

Swine manure was collected from swine barns at the USDA-ARS U.S. Meat Animal Research Center in Clay Center, Nebraska, USA. The pigs were fed a corn-based diet with soybean meal $(80.2 \%$ ground corn, $16.6 \%$ soybean meal with the remainder being supplemental vitamins, minerals, amino acids, and antibiotics). The manure was mixed with equal mass of distilled water to form a pourable slurry, and was transferred to individual glass beakers where the treatments were applied. The swine manure slurry had total solids contents (dry matter, DM) of $13.2 \%$, and the volatile solids content was $20.0 \%$ of DM ( $2.6 \%$ ash).

\subsection{VOC concentration and flux measurement}

Volatile organic compound flux was measured in a small rectangular wind tunnel of $51 \mathrm{~mm}$ height, $305 \mathrm{~mm}$ length, and $152 \mathrm{~mm}$ width with a $5 \mathrm{~mm}$ thick Plexiglas top. The wind tunnel has been described previously (Parker et al., in press). Sweep air entered the wind tunnel through 17 holes (6-mm dia.) in three rows at heights of $17 \mathrm{~mm}$ ( 6 holes), $30 \mathrm{~mm}$ (5 holes), and $43 \mathrm{~mm}$ ( 6 holes) above the base. Air exited the tunnel through three 10$\mathrm{mm}$ diameter holes equally spaced at height $27 \mathrm{~mm}$ above the base at the opposite end of the tunnel. As the sweep air was passed through activated carbon and Drierite ${ }^{\mathrm{TM}}$ filters to remove VOCs and moisture, it was verified as VOC free. The sweep air flow rate was controlled using a valved rotameter with scale of 0 1.2 $\mathrm{L} \mathrm{min}^{-1}$ (Omega Engineering, Stamford, CT, USA).

A round Petri dish $(138 \mathrm{~mm}$ dia $\times 13 \mathrm{~mm}, 200 \mathrm{~mL})$ containing the swine slurry sample was placed in the center of the wind tunnel. The wind tunnel was operated at a sweep air flow rate of $1 \mathrm{~L} \mathrm{~min}^{-1}$, corresponding to sweep air volumetric exchange rate of 0.4 exchanges $\min ^{-1}$. At this air flow rate, the equivalent distilled water evaporation rate, measured using dry sweep air with the same size Petri dish at $21.0^{\circ} \mathrm{C}$, was $1.2 \mathrm{~mm} \mathrm{~d}^{-1}$.

A fraction of the air exiting the wind tunnel was sampled using stainless steel sorbent tubes $(89 \mathrm{~mm} \times 6.4 \mathrm{~mm}$ OD) packed with $200 \mathrm{mg}$ Tenax $\mathrm{TA}^{\circledR}$ sorbent. Conditioned and capped tubes were purchased new from the manufacturer (Markes International Inc., Wilmington, DE, USA). Prior to first use, tubes were conditioned for $2 \mathrm{~h}$ at $230^{\circ} \mathrm{C}$ and verified to be clean before sampling. Air was pulled through the sorbent tubes at a flow rate of $75 \mathrm{~mL} \mathrm{~min}^{-1}$ for $2 \mathrm{~min}$ for a sample volume of $150 \mathrm{~mL}$ using a vacuum pump (Pocket pump 210 series, SKC Inc., Eighty Four, PA, USA). All sampling was conducted at room temperature of $21.0^{\circ} \mathrm{C}$.

\subsection{GC/MS with thermal desorption}

Sorbent tube samples were analyzed using a thermal desorption-gas chromatography-mass spectrometry (TD-GC-MS) system. The TD system consisted of a Markes Unity 2 thermal desorber with Ultra 2 autosampler (Markes International Inc., Wilmington, DE, USA). Samples were quantified with an Agilent 7890A GC with Agilent 5975C MS (Agilent Technologies, Inc., Santa Clara, CA, USA).

In the TD system, samples were initially purged for $2 \mathrm{~min}$ $\left(40 \mathrm{~mL} \mathrm{~min}^{-1}, 20^{\circ} \mathrm{C}\right)$ to remove water and air. The tube was desorbed for $10 \mathrm{~min}$ at $280^{\circ} \mathrm{C}$ with a carrier gas flow of $50 \mathrm{~mL} \mathrm{~min}{ }^{-1}$ and trapped on the cold trap maintained at $-10^{\circ} \mathrm{C}$. The cold trap was heated to $320^{\circ} \mathrm{C}$ for $3 \mathrm{~min}$ with a carrier gas flow of 20 , and $1.4 \mathrm{~mL} \mathrm{~min}^{-1}$ was transferred to the column in the GC-MS. In the GC oven, the column was held at $40^{\circ} \mathrm{C}$ for $3 \mathrm{~min}$, ramped to $230^{\circ} \mathrm{C}$ at $8{ }^{\circ} \mathrm{C} \mathrm{min}^{-1}$, then held at $230^{\circ} \mathrm{C}$ for $5 \mathrm{~min}$ for a total run time of $31.8 \mathrm{~min}$. The polar analytical column was an Agilent Innowax, $30 \mathrm{~m} \times 0.25 \mathrm{~mm}$ ID capillary column (polyethylene glycol, $0.25 \mu \mathrm{m}$ film thickness).

\subsection{Standards and calibration}

Samples were analyzed for VFAs, phenolics, and indolics. Standard solutions were prepared by diluting known masses of pure chemicals with methanol. Standards were prepared using serial dilutions, and injected onto clean tubes using a calibration solution loading rig (CSLR; Markes International Inc., Wilmington, DE, USA). The liquid calibration standard was introduced through the CSLR injector septum in clean bottled air carrier gas $\left(75 \mathrm{~mL} \mathrm{~min}^{-1}\right)$ using a standard GC syringe. Within the linear range, standard curves were fit using linear regression with the curve forced through the origin.

All sorbent tubes were conditioned with the TD system and analyzed on the GC-MS prior to sampling to verify that clean tubes were used in the experiment. Regression slopes and $r^{2}$ values for each compound are shown in Table 2.

\subsection{Statistical analysis}

Data from Experiments 1 to 4 were graphed and visually examined to determine the optimum application rates of HRP, SBP, and peroxides. The data from Experiment 5 were analyzed as a completely randomized design with repeated measures in time using the SAS MIXED Procedure (SAS Inst. Inc., Cary, NC). Fixed effects were treatment, replicate, time, and the treatment $\times$ time interaction. Replicate $\times$ treatment was the subject of the repeated measures, and several covariance structures were tested. The covariance structure resulting in the smallest Akaike and Schwarz Bayesian criteria were considered most appropriate for analysis. When significant $(P<0.05)$ treatment $\times$ time interactions were detected using single-degree-of-freedom $F$-tests, pairwise comparisons of the simple-effects means were conducted within the PDIFF option of SAS. Effects were considered significant at $P<0.05$.

\subsection{Odor activity value}

Odor activity values (OAV), defined as the ratio of the concentration of a compound to the human odor threshold for that compound (Guadagni et al., 1963; Leffingwell and Leffingwell, 1991; Parker et al., in press), were calculated to assess the importance of individual chemical compound reductions (or increases) on odor. Compounds with large OAV are more likely to contribute to the overall odor of a complex odor mixture. Odor activity values were calculated using published odor thresholds for each compound (Parker et al., in press). The relative contribution of each compound was calculated by dividing the OAV for the individual compound by the sum of the OAVs for all compounds (Guadagni et al., 1963; Leffingwell and Leffingwell, 1991). 
Table 2

Summary of compounds quantified by GC/MS in the study, linear range and regression statistics for standard curves.

\begin{tabular}{|c|c|c|c|c|c|c|}
\hline Compound & $\mathrm{MW}^{\mathrm{a}}$ & Retention time (min) & MS quan ion ${ }^{a}$ & Linear range (ng) & Linear regression slope (B1) & Linear regression $\left(r^{2}\right)$ \\
\hline Phenol & 94.1 & 20.2 & 94 & $5.7-1105$ & $1.31 \mathrm{E}-04$ & 0.992 \\
\hline 4-Methylphenol & 108.1 & 21.1 & 107 & $5.2-1045$ & $1.37 \mathrm{E}-04$ & 0.973 \\
\hline Indole & 117.1 & 25.2 & 117 & $6.3-1283$ & $6.60 \mathrm{E}-05$ & 0.988 \\
\hline Skatole & 131.2 & 25.6 & 130 & $7.1-722$ & $4.30 \mathrm{E}-05$ & 0.969 \\
\hline Acetic acid & 60.0 & 12.4 & 60 & $2.6-2602$ & $8.18 \mathrm{E}-04$ & 0.997 \\
\hline Propanoic acid & 74.1 & 13.8 & 74 & $2.5-2485$ & $7.58 \mathrm{E}-04$ & 0.999 \\
\hline Isobutyric acid & 88.1 & 14.2 & 43 & $2.3-2344$ & $4.53 \mathrm{E}-04$ & 0.997 \\
\hline Butyric acid & 88.1 & 15.1 & 60 & $2.4-2401$ & $2.94 \mathrm{E}-04$ & 0.995 \\
\hline Isovaleric acid & 102.1 & 15.7 & 60 & $2.3-2290$ & $2.69 \mathrm{E}-04$ & 0.991 \\
\hline Valeric acid & 102.1 & 16.7 & 60 & $2.3-2342$ & $2.51 \mathrm{E}-04$ & 0.990 \\
\hline Hexanoic acid & 116.2 & 18.1 & 60 & $2.3-2348$ & $2.97 \mathrm{E}-04$ & 0.978 \\
\hline Heptanoic acid & 130.2 & 19.5 & 60 & $2.3-2278$ & $3.57 \mathrm{E}-04$ & 0.982 \\
\hline
\end{tabular}

a $\mathrm{MW}=$ molecular weight, $\mathrm{MS}=$ mass spectrometry quantification ion.

\section{Results and discussion}

\subsection{Optimization of SBPP when applied to standard solutions (Experiment 1)}

Experiment 1 varied the concentration of SBP with a constant level of $\mathrm{H}_{2} \mathrm{O}_{2}$. Although the flux of phenol and 4-methylphenol from the standard solution both decreased with increasing SBP application rate, 4-methylphenol was more readily treated than phenol (Fig. 1a). There was a $96.5 \%$ reduction in 4-methylphenol flux with SBP application rate of around $1.0 \mathrm{~g} \mathrm{~L}^{-1}$. Reductions of 4-methylphenol were $99.9 \%, 99.8 \%$, and $96.9 \%$ at SBP application rates of $2.5,5.0$, and $10.0 \mathrm{~g} \mathrm{~L}^{-1}$, respectively. Thus, increasing the SBP application rate from 1.0 to $2.5 \mathrm{~g} \mathrm{~L}^{-1}$ only improved the reduction by an additional $3.4 \%$. However, in terms of potential odor emissions, the $2.5 \mathrm{~g} \mathrm{~L}^{-1}$ application rate would be recommended. This is because the geometric mean odor threshold of $1.3 \mu \mathrm{g} \mathrm{m}^{-3}$ for 4-methylphenol (Parker et al., in press) equates to a flux of $0.09 \mu \mathrm{g} \mathrm{m}^{-2} \mathrm{~min}^{-1}$ from the wind tunnel, and 4-methylphenol fluxes were 7.28 and $0.22 \mu \mathrm{g} \mathrm{m}^{-2} \mathrm{~min}^{-1}$ at SBP application rates of 1.0 and $2.5 \mathrm{~g} \mathrm{~L}^{-1}$, respectively. Thus, the SBP rate of $2.5 \mathrm{~g} \mathrm{~L}^{-1}$ reduced the 4-methylphenol flux almost to the odor threshold. This feature is important because at this concentration humans would no longer be able to smell the 4-methylphenol. The effectiveness of 4-methylphenol reduction decreased slightly at the highest SBP application rate of $10.0 \mathrm{~g} \mathrm{~L}^{-1}$. It is unknown whether this is a direct effect of higher SBP application rate, or simply an artifact of experimental variation.

The geometric mean odor threshold for phenol $\left(206 \mu \mathrm{g} \mathrm{m}^{-3}\right)$ is more than two orders of magnitude greater than that for 4-methylphenol (Parker et al., in press), and consequently 4-methylphenol is often implicated as the most important odorous VOC at animal

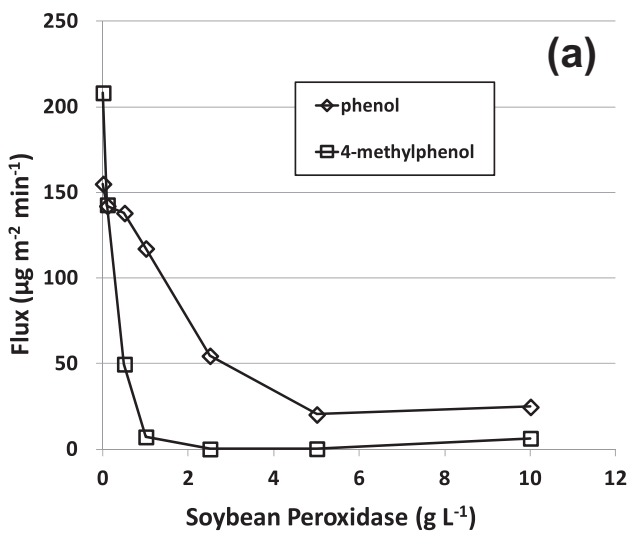

feeding operations (Parker, 2007). A majority of the urinary phenols excreted by livestock are 4-methylphenol and, as the dietary protein increases, 4-methylphenol excretion increases as a result of microbial amino acid fermentation in the lower gut (Mackie et al., 1998). In recent years, cattle and swine diets contain increased levels of distillers grains and soluble (DGS), a byproduct of the growing ethanol industry. There is approximately three times more protein in DGS than in corn. The fact that SBP selectively treats 4-methylphenol faster than phenol (Fig. 1a) is a tremendous advantage for odor reduction.

For phenol, the flux decreased almost linearly for SBP application rates from 0 to $5.0 \mathrm{~g} \mathrm{~L}^{-1}$ (Fig. 1a) but there were minimal differences in percent reduction between SBP application rates of 5.0 and $10.0 \mathrm{~g} \mathrm{~L}^{-1}$ (86.9\% and $84.0 \%$ reductions, respectively). At the SBP application rate of $2.5 \mathrm{~g} \mathrm{~L}^{-1}$, there was a $65 \%$ reduction in the phenol emission rate in addition to the $99.9 \%$ reduction in 4 -methylphenol. With an SBP nominal activity of $0.77 \mathrm{U} \mathrm{mg}^{-1}$, the SBP application rate of $2.5 \mathrm{~g} \mathrm{~L}^{-1}$ was equivalent to $1925 \mathrm{U} \mathrm{L}^{-1}$ $\left(2.5 \mathrm{~g} \mathrm{~L}^{-1} \times 1000 \mathrm{mg} \mathrm{g}^{-1} \times 0.77 \mathrm{U} \mathrm{mg}^{-1}\right)$. Caza et al. (1999) reported a $95 \%$ reduction in phenolic substrate when treated with $800 \mathrm{U} \mathrm{L}^{-1}$ of SBP. Given that we had two phenolic substrates (phenol and 4-methylphenol), then Caza's recommendation of $800 \mathrm{U} \mathrm{L}^{-1}$ would equate to $1600 \mathrm{U} \mathrm{L}^{-1}$, which compares favorably to the $1925 \mathrm{U} \mathrm{L}^{-1}$ in our research. Flock et al. (1999) measured a $60 \%$ reduction in phenol solution (with $1000 \mathrm{ppm}$ initial concentration) with the addition of $40 \mathrm{~g} \mathrm{~L}^{-1}$ fresh soybean hulls.

\subsection{Optimization of $\mathrm{H}_{2} \mathrm{O}_{2}$ when applied to standard solutions (Experiment 2)}

Experiment 2 varied the concentration of $\mathrm{H}_{2} \mathrm{O}_{2}$ with a constant level of SBP. There were considerable differences in the treatment

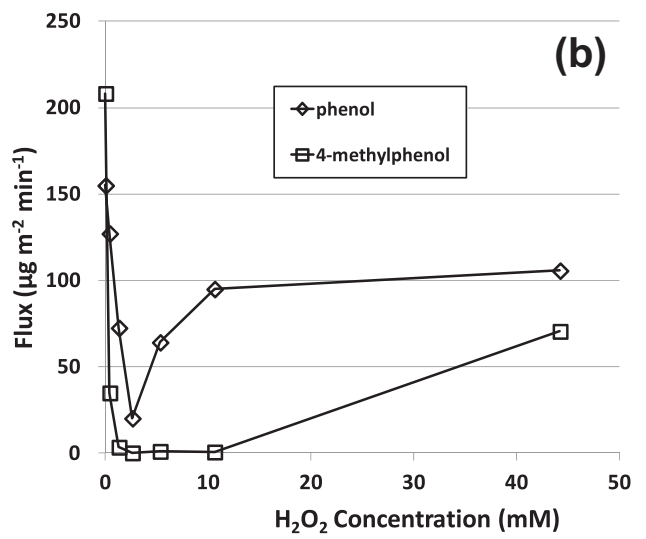

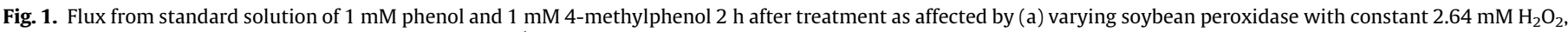
and (b) varying $\mathrm{H}_{2} \mathrm{O}_{2}$ concentration with constant $5 \mathrm{~g} \mathrm{~L}^{-1} \mathrm{SBP}$ (Experiments 1 and 2). 
efficacies of phenol and 4-methylphenol at different $\mathrm{H}_{2} \mathrm{O}_{2}$ concentrations (Fig. 1b). While the fluxes of both compounds decreased quickly between $\mathrm{H}_{2} \mathrm{O}_{2}$ concentrations of 0 and $2.6 \mathrm{mM}$, the phenol flux actually increased above $2.4 \mathrm{mM}$. For the phenol treatment there was a narrow window of effective $\mathrm{H}_{2} \mathrm{O}_{2}$ concentration, while for 4-methylphenol the window was much broader. The 4-methylphenol flux stayed low up to $10.6 \mathrm{mM}$, with percent reductions of $98.3 \%$ to $98.6 \%$ between 1.3 and $10.6 \mathrm{mM}$, respectively (Fig. 1b). As stated previously, the odor threshold for 4-methylphenol is about two orders of magnitude lower than that for phenol. Thus, this broad window of effective $\mathrm{H}_{2} \mathrm{O}_{2}$ concentration for 4-methylphenol would be desirable for odor reduction. The 4-methylphenol flux was at a minimum $\left(0.34 \mu \mathrm{g} \mathrm{m}^{-2} \mathrm{~min}^{-1}\right)$ at an $\mathrm{H}_{2} \mathrm{O}_{2}$ concentration of $2.6 \mathrm{mM}$. Thus, for the standard solution of phenol and 4-methylphenol, the optimum $\mathrm{H}_{2} \mathrm{O}_{2}$ concentration was $2.6 \mathrm{mM}$, although differences were minimal between 1.3 and $10.6 \mathrm{mM} \mathrm{H}_{2} \mathrm{O}_{2}$.

The optimum $\mathrm{H}_{2} \mathrm{O}_{2}$ concentration of $2.6 \mathrm{mM}$ for the sum of both phenolic compounds compares very favorably with Caza et al. (1999), who reported optimum $\mathrm{H}_{2} \mathrm{O}_{2}$ concentrations of 1.2 per mM of phenol and 0.9 per mM 4-methylphenol (sum of $2.1 \mathrm{mM}$ ).

\subsection{Optimization of SBPP when applied toswine manure (Experiment 3)}

Experiment 3 varied the concentration of SBP with a constant level of $\mathrm{H}_{2} \mathrm{O}_{2}$. The concentrations of phenol and 4-methylphenol in the manure slurry were 0.065 and $0.267 \mathrm{mM}$, respectively. Even though these concentrations were considerably less than the $1 \mathrm{mM}$ for each compound in the standard solution, it took more than 10 times the SBP for optimal treatment in the manure than in the standard solution. While the exact cause for this increased SBP requirement is unknown, it is likely that there were various interfering constituents in the manure but not the standard solution.
For untreated swine manure, the flux of 4-methylphenol (range 31-46 $\mu \mathrm{g} \mathrm{m}^{-2} \mathrm{~min}^{-1}$ ) was considerably greater than for the other VOCs analyzed (Fig. 2). The flux of 4-methylphenol decreased with increasing SBP rate and the SBP was effective in treating 4-methylphenol for the full $72 \mathrm{~h}$ duration of the experiment. The fluxes of indole and skatole decreased by $30-50 \%$. Indole is the product of tryptophan metabolism (Macfarlane and Macfarlane, 1995) and it has been reported to increase in swine feces when feeding dried distillers grains (Hawe et al., 1992), which again demonstrates the importance of SBP in abatement of odor in swine manure.

An interesting aspect of these results was that the lowest SBP rate of $5.0 \mathrm{~g} \mathrm{~L}^{-1}$ actually increased 4-methylphenol emissions up to $50 \%$ over the controls (Fig. 2). The cause in this bump, which had disappeared by $25 \mathrm{~g} \mathrm{~L}^{-1}$ (Fig. 2), is still unknown but it could be because the dry SBP preferentially absorbs water but not VOCs, leaving higher concentrations of VOC in solution. A similar phenomenon was observed by the authors in experiments involving the treatment of manure with zeolite (Donnell et al., 2008).

Two hours after treatment, there was a $69.1 \%$ reduction in 4methylphenol at SBP application rate of $50 \mathrm{~g} \mathrm{~L}^{-1}$. Since there was little difference in 4-methylphenol flux between the 50,75 , and $100 \mathrm{~g} \mathrm{~L}^{-1}$ SBP application rates after $72 \mathrm{~h}$ (Fig. 2), the SBP application rate of $50 \mathrm{~g} \mathrm{~L}^{-1}$ was concluded to be the optimum for swine manure.

\subsection{Optimization of $\mathrm{H}_{2} \mathrm{O}_{2}$ or $\mathrm{CaO}_{2}$ when applied to swine manure (Experiment 4)}

Experiment 4 compared concentrations of $\mathrm{H}_{2} \mathrm{O}_{2}$ and $\mathrm{CaO}_{2}$ with a constant level of SBP. While it only required $2.64 \mathrm{mM} \mathrm{H}_{2} \mathrm{O}_{2}$ to treat the $2 \mathrm{mM}$ phenolic standard solution (Fig. 1b), it took approximately five to nine times more peroxide for the manure (Fig. 2).
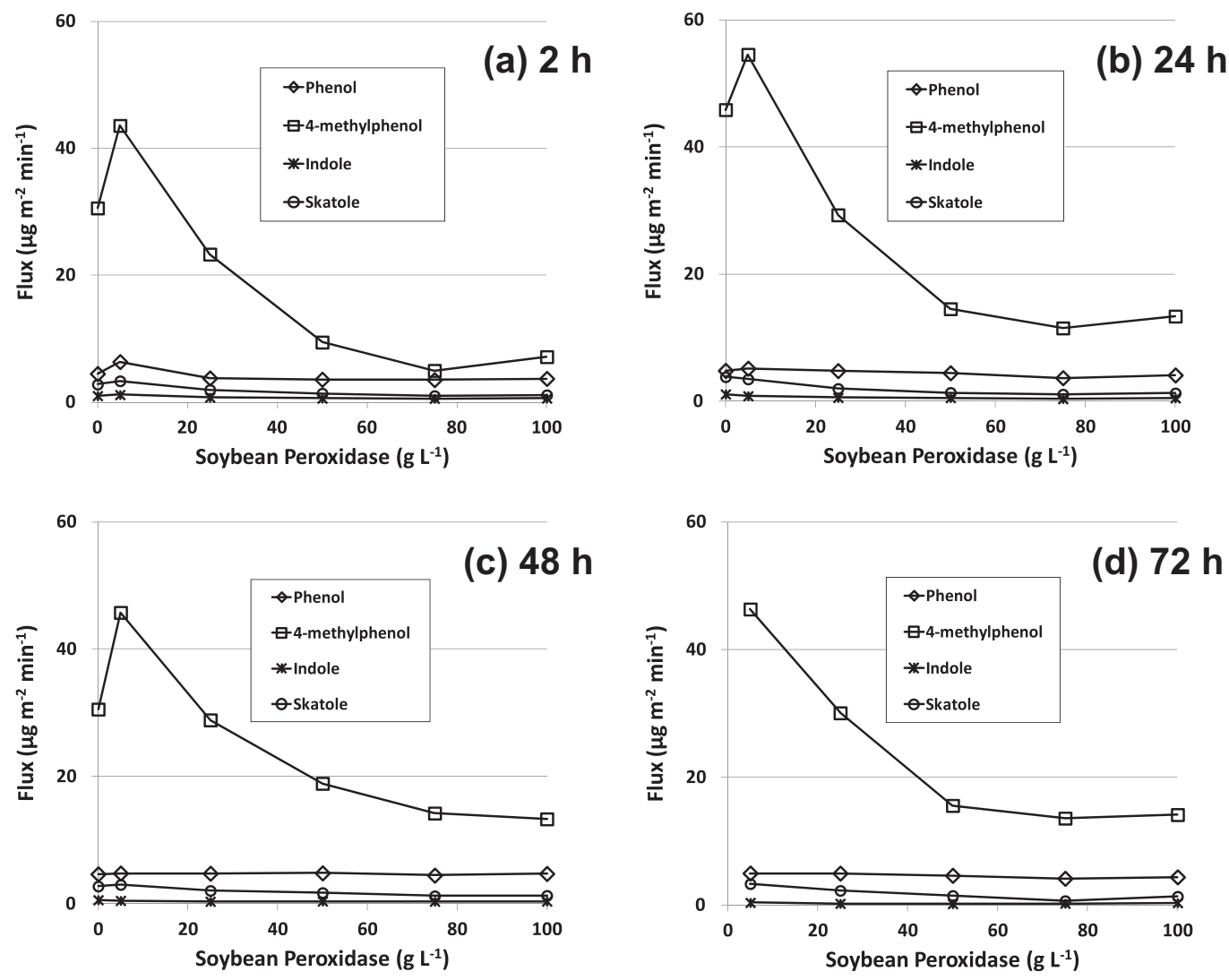

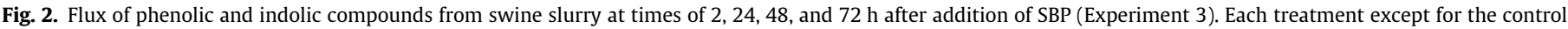
received SBP plus $14.6 \mathrm{mM} \mathrm{H}_{2} \mathrm{O}_{2}$. 
Table 3

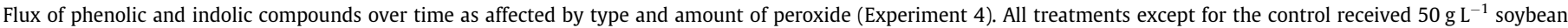
peroxidase (SBP) plus peroxide in the amount shown.

\begin{tabular}{|c|c|c|c|c|c|c|c|}
\hline & Control & $\mathrm{H}_{2} \mathrm{O}_{2} 14.6 \mathrm{mM}$ & $\mathrm{H}_{2} \mathrm{O}_{2} 38.0 \mathrm{mM}$ & $\mathrm{CaO}_{2} 14.6 \mathrm{mM}$ & $\mathrm{CaO}_{2} 22.1 \mathrm{mM}$ & $\mathrm{CaO}_{2} 38.0 \mathrm{mM}$ & $\mathrm{CaO}_{2} 76.0 \mathrm{mM}$ \\
\hline \multicolumn{8}{|c|}{ Flux after $2 h\left(\mu g m^{-2} \min ^{-1}\right)$} \\
\hline Phenol & 3.97 & 3.60 & 4.20 & 3.74 & 3.45 & 3.20 & 1.80 \\
\hline 4-Methylphenol & 24.64 & 11.1 & 8.80 & 9.44 & 2.43 & 5.85 & 2.03 \\
\hline Indole & 9.63 & 0.50 & 0.50 & 0.96 & 1.31 & 1.51 & 2.21 \\
\hline Skatole & 10.21 & 1.0 & 1.2 & 1.61 & 1.77 & 2.67 & 5.13 \\
\hline \multicolumn{8}{|c|}{ Flux after $24 \mathrm{~h}\left(\mu \mathrm{g} \mathrm{m} \mathrm{m}^{-2} \mathrm{~min}^{-1}\right)$} \\
\hline Phenol & 5.19 & 4.11 & 4.23 & 2.98 & 2.20 & 1.37 & 1.19 \\
\hline 4-Methylphenol & 55.86 & 18.72 & 13.65 & 3.26 & 0.82 & 2.11 & 1.30 \\
\hline Indole & 20.91 & 0.74 & 0.62 & 1.19 & 1.31 & 1.18 & 2.02 \\
\hline Skatole & 22.71 & 1.98 & 1.85 & 1.76 & 1.76 & 2.03 & 4.25 \\
\hline \multicolumn{8}{|c|}{ Flux after $48 \mathrm{~h}\left(\mu \mathrm{g} \mathrm{m} \mathrm{min}^{-1}\right)$} \\
\hline Phenol & 5.91 & 4.15 & 3.77 & 3.70 & 2.11 & 2.05 & 1.03 \\
\hline 4-Methylphenol & 58.35 & 18.49 & 13.56 & 3.15 & 1.11 & 4.33 & 1.62 \\
\hline Indole & 22.29 & 0.38 & 0.40 & 0.91 & 1.13 & 1.32 & 2.09 \\
\hline Skatole & 24.98 & 1.85 & 1.64 & 1.39 & 1.44 & 2.40 & 4.57 \\
\hline
\end{tabular}

This increase was likely because some of the peroxide was inactivated by the organic matter in the manure, making it unavailable for oxidation in the peroxidase enzyme process.

Experiment 4 further demonstrated this limitation of liquid $\mathrm{H}_{2} \mathrm{O}_{2}$, especially in contrast to the alternative solid $\mathrm{CaO}_{2}$ (Table 3 ). Two hours after treatment, there was little difference in 4methylphenol reductions between the $14.6 \mathrm{mM} \mathrm{CaO}$ and $\mathrm{H}_{2} \mathrm{O}_{2}$ treatments (61.7\% and 55.0\%, respectively). However, after $24 \mathrm{~h}$ the $\mathrm{CaO}_{2}$ treatment performed considerably better than did $\mathrm{H}_{2} \mathrm{O}_{2}$, with 4-methylphenol reductions of $94.2 \%$ and $66.5 \%$, respectively. For 4-methylphenol, the $\mathrm{CaO}_{2}$ treatments generally outperformed the $\mathrm{H}_{2} \mathrm{O}_{2}$ treatments by about $20-30 \%$.

Percent reductions in phenol were minimal after $2 \mathrm{~h}$, but after 24 and $48 \mathrm{~h}$ all treatments became more effective with percent reductions of $30-80 \%$. As for 4-methylphenol, the $\mathrm{CaO}_{2}$ treatments performed better than the $\mathrm{H}_{2} \mathrm{O}_{2}$ treatments. Percent reduction in phenol flux was positively correlated with $\mathrm{CaO}_{2}$ concentration at 24 and $48 \mathrm{~h}$, with $82.5 \%$ reduction in phenol flux at the highest $\mathrm{CaO}_{2}$ concentration of $76.0 \mathrm{mM}$. Both peroxides were effective at reducing indole and skatole flux, with percent reductions of about 80-98\% (Table 3). Overall, based on the 4-methylphenol reductions, we concluded that the optimum $\mathrm{H}_{2} \mathrm{O}_{2}$ and $\mathrm{CaO}_{2}$ concentrations were 14.6 and $22.1 \mathrm{mM}$, respectively.

While $\mathrm{CaO}_{2}$ outperformed $\mathrm{H}_{2} \mathrm{O}_{2}$ for the reduction of phenolic and indolic compounds, another potential benefit of $\mathrm{CaO}_{2}$ is that it is a dry powder, similar to the SBP. Should SBP become a potential additive to swine barns or lagoons, the potential exists for mixing the two powders (SBP and $\mathrm{CaO}_{2}$ ) in dry form for topical application. Future research will focus on topical application in laboratory and field experiments.

\subsection{Replicated experiment (Experiment 5)}

The optimum $\mathrm{H}_{2} \mathrm{O}_{2}$ and $\mathrm{CaO}_{2}$ concentrations (Table 3) were confirmed by Experiment 5 in which the data for each time point were obtained in triplicate. The treatment $\times$ time interactions were significant $(P<0.05)$ for all compounds. Therefore, only the treatment $\times$ time means were statistically compared (Table 4 ). At the optimum SBP application rate for swine manure of $50 \mathrm{~g} \mathrm{~L}^{-1}$ (as determined in Fig. 2), emissions of the primary odorant 4-methylphenol were reduced by $62 \%$ and $98 \%(P<0.0001)$ after $24 \mathrm{~h}$ for $\mathrm{H}_{2} \mathrm{O}_{2}$ and $\mathrm{CaO}_{2}$, respectively. After $48 \mathrm{~h}$, the $\mathrm{CaO}_{2}$ treatment remained effective with $92 \%$ reduction $(P<0.0001)$, but there was no difference between the $\mathrm{H}_{2} \mathrm{O}_{2}$ treatment and the control $(P=0.28)$ (Fig. 3b). However, neither of the SBP treatments were effective at reducing phenol emissions (Fig. 3a).

After $24 \mathrm{~h}$, SBP was effective at reducing indole concentrations by $60 \%(P<0.0001)$ for $\mathrm{H}_{2} \mathrm{O}_{2}$ and $19 \%(P=0.039)$ for $\mathrm{CaO}_{2}$ but after $48 \mathrm{~h}$, the $\mathrm{CaO}_{2}$ treatment actually increased indole emissions by $69 \%(P<0.0001)$ while the $\mathrm{H}_{2} \mathrm{O}_{2}$ treatment was again

Table 4

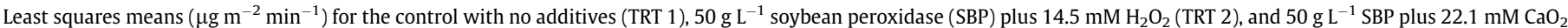
(TRT 3) of Experiment 5.

\begin{tabular}{|c|c|c|c|c|c|c|c|c|c|}
\hline & \multicolumn{3}{|l|}{$2 \mathrm{~h}$} & \multicolumn{3}{|l|}{$24 \mathrm{~h}$} & \multicolumn{3}{|l|}{$48 \mathrm{~h}$} \\
\hline & $\begin{array}{l}\text { Control (TRT } \\
\text { 1) }\end{array}$ & $\begin{array}{l}\mathrm{H}_{2} \mathrm{O}_{2} \text { (TRT } \\
\text { 2) }\end{array}$ & $\begin{array}{l}\mathrm{CaO}_{2}(\mathrm{TRT} \\
3)\end{array}$ & $\begin{array}{l}\text { Control (TRT } \\
\text { 1) }\end{array}$ & $\begin{array}{l}\mathrm{H}_{2} \mathrm{O}_{2} \text { (TRT } \\
2 \text { ) }\end{array}$ & $\begin{array}{l}\mathrm{CaO}_{2}(\mathrm{TRT} \\
3)\end{array}$ & $\begin{array}{l}\text { Control (TRT } \\
\text { 1) }\end{array}$ & $\begin{array}{l}\mathrm{H}_{2} \mathrm{O}_{2} \text { (TRT } \\
2 \text { ) }\end{array}$ & $\begin{array}{l}\mathrm{CaO}_{2} \text { (TRT } \\
3)\end{array}$ \\
\hline Phenol & $2.82 \mathrm{a}$ & $2.55 \mathrm{a}$ & $2.59 \mathrm{a}$ & $3.72 \mathrm{f}$ & $3.34 \mathrm{f}$ & $2.16 \mathrm{~g}$ & $3.04 \mathrm{y}$ & $3.80 \mathrm{x}$ & $3.32 \mathrm{xy}$ \\
\hline 4-Methylphenol & $39.20 \mathrm{a}$ & $14.00 \mathrm{~b}$ & $7.20 \mathrm{c}$ & $75.83 \mathrm{f}$ & $28.47 \mathrm{~g}$ & $1.23 \mathrm{~h}$ & $23.93 x$ & $20.47 x$ & $1.97 \mathrm{y}$ \\
\hline Indole & $0.83 \mathrm{~b}$ & $0.50 \mathrm{c}$ & $0.99 \mathrm{a}$ & $1.10 \mathrm{f}$ & $0.44 \mathrm{~h}$ & $0.89 \mathrm{~g}$ & $0.24 \mathrm{y}$ & $0.22 \mathrm{y}$ & $0.77 \mathrm{x}$ \\
\hline Skatole & $2.21 \mathrm{a}$ & $1.22 \mathrm{~b}$ & $2.26 \mathrm{a}$ & $5.20 \mathrm{f}$ & $2.25 \mathrm{~g}$ & $1.73 \mathrm{~h}$ & $1.22 \mathrm{y}$ & 1.59 xy & $1.84 \mathrm{x}$ \\
\hline Acetic Acid & $38.92 \mathrm{a}$ & $37.85 \mathrm{a}$ & $17.54 \mathrm{a}$ & $68.30 \mathrm{f}$ & $60.61 \mathrm{f}$ & $15.04 \mathrm{f}$ & $31.79 \mathrm{y}$ & $283.80 \mathrm{x}$ & $53.72 \mathrm{y}$ \\
\hline Propionic Acid & $27.05 \mathrm{a}$ & $29.32 \mathrm{a}$ & $2.59 \mathrm{~b}$ & $77.35 \mathrm{f}$ & $70.79 \mathrm{f}$ & $2.76 \mathrm{~g}$ & $20.25 \mathrm{y}$ & $260.93 x$ & $13.08 \mathrm{y}$ \\
\hline Isobutyric Acid & $5.25 \mathrm{a}$ & $6.92 \mathrm{a}$ & $0.74 \mathrm{~b}$ & $14.22 \mathrm{f}$ & $14.41 \mathrm{f}$ & $0.79 \mathrm{~g}$ & $3.90 \mathrm{y}$ & $50.68 \mathrm{x}$ & $2.54 \mathrm{y}$ \\
\hline Butyric Acid & $17.73 \mathrm{a}$ & $18.21 \mathrm{a}$ & $1.31 \mathrm{~b}$ & $60.67 \mathrm{f}$ & $57.66 \mathrm{f}$ & $1.34 \mathrm{~g}$ & $11.13 \mathrm{y}$ & $238.17 x$ & $5.76 \mathrm{y}$ \\
\hline Isovaleric Acid & $3.17 \mathrm{a}$ & $3.22 \mathrm{a}$ & $0.34 \mathrm{~b}$ & $11.15 \mathrm{f}$ & $11.07 \mathrm{f}$ & $0.31 \mathrm{~g}$ & $2.15 \mathrm{y}$ & $50.50 \mathrm{x}$ & $1.38 \mathrm{y}$ \\
\hline Valeric Acid & $2.94 \mathrm{a}$ & $2.34 \mathrm{a}$ & $0.62 \mathrm{a}$ & $9.98 \mathrm{f}$ & $10.96 \mathrm{f}$ & $0.80 \mathrm{~g}$ & $2.09 \mathrm{y}$ & $64.78 \times$ & $2.21 \mathrm{y}$ \\
\hline Hexanoic Acid & $0.80 \mathrm{a}$ & $0.58 \mathrm{a}$ & $0.65 \mathrm{a}$ & $0.99 \mathrm{f}$ & $1.02 \mathrm{f}$ & $0.34 \mathrm{f}$ & $0.33 \mathrm{y}$ & $5.14 \mathrm{x}$ & $0.76 \mathrm{y}$ \\
\hline Heptanoic Acid & $0.38 \mathrm{a}$ & $0.41 \mathrm{a}$ & $0.12 \mathrm{~b}$ & $0.29 \mathrm{~g}$ & $0.63 \mathrm{f}$ & $0.12 \mathrm{~g}$ & $0.30 \mathrm{y}$ & $0.88 \mathrm{x}$ & $0.39 \mathrm{y}$ \\
\hline Total VFAs & $96.24 \mathrm{ab}$ & $98.85 \mathrm{a}$ & $23.91 b$ & $242.9 \mathrm{f}$ & $227.2 \mathrm{f}$ & $21.50 \mathrm{~g}$ & $82.24 \mathrm{y}$ & $954.9 \mathrm{x}$ & $79.83 \mathrm{y}$ \\
\hline $\begin{array}{l}\text { Manure } \mathrm{pH}(\mathrm{pH} \\
\text { units) }\end{array}$ & $6.00 \mathrm{~b}$ & $6.00 \mathrm{~b}$ & $9.00 \mathrm{a}$ & $5.80 \mathrm{~h}$ & $5.90 \mathrm{~g}$ & $9.17 \mathrm{f}$ & $5.80 \mathrm{y}$ & $5.07 \mathrm{z}$ & $6.20 x$ \\
\hline
\end{tabular}


indistinguishable from the control $(P=0.73)$. Skatole emissions were significantly reduced with both peroxide treatments at $24 \mathrm{~h}$ $(P<0.0001)$, but at $48 \mathrm{~h}$ the $\mathrm{CaO}_{2}$ treatment was $51 \%$ greater than the control $(P=0.005)$.

The VFAs were dominated by acetic acid, propionic acid, and butyric acid, which comprised from $77 \%$ to $91 \%$ of the total VFAs (Table 4). Similar percentages in swine manure have been reported by others (Velthof et al., 2005; Conn et al., 2007). The $\mathrm{CaO}_{2}$ treatment reduced the total VFA flux by $75 \%$ at $2 \mathrm{~h}(P=0.053)$ and $91 \%$ at $24 \mathrm{~h}(P<0.0001)$ (Fig. 3e). However, after $48 \mathrm{~h}$ there was no difference between VFA flux for the control and $\mathrm{CaO}_{2}$ treatments $(P=0.90)$. More remarkably, after $48 \mathrm{~h}$ the $\mathrm{H}_{2} \mathrm{O}_{2}$ treatment increased total VFA emissions by $1060 \%$ (more than 10 -fold, $P<0.0001$ ). This phenomenon is most likely the result of manure $\mathrm{pH}$. The manure used in this research had low initial $\mathrm{pH}$, but still within the range of expected manure $\mathrm{pH}$ values for anaerobic manure. In laboratory studies, Miller and Varel (2003) reported pH values of 6.1-5.4 during the incubation of swine manure slurry. As compared to the control $(\mathrm{pH}=5.8)$, there was also a decrease in manure $\mathrm{pH}$ of 0.7 units for the $\mathrm{H}_{2} \mathrm{O}_{2}$ treatment $(\mathrm{pH}=5.1)$ after $48 \mathrm{~h}$. Volatilization of VFAs has been shown to be highly dependent on manure $\mathrm{pH}$ (Miller and Berry, 2005). The $\mathrm{p} K_{\mathrm{a}}$ values for VFAs are approximately 4.8 and at low pH values the VFAs exist in the volatile non-ionized form, whereas at higher $\mathrm{pH}$ values they exist in the non-volatile ionized form. Thus, as the $\mathrm{pH}$ for the $\mathrm{H}_{2} \mathrm{O}_{2}$ treated manure neared the $\mathrm{p} K_{\mathrm{a}}$ for VFAs there was a considerable increase in VFA emissions (Table 4). In contrast, $\mathrm{CaO}_{2}$ treatment increased the manure $\mathrm{pH}$ at 2 and $24 \mathrm{~h}$ by about three $\mathrm{pH}$ units $(\mathrm{pH}>9)$, considerably above the $\mathrm{p} K_{\mathrm{a}}$ values for VFAs, and at $48 \mathrm{~h}$ the $\mathrm{pH}$ was still significantly greater than the starting pH (Table 4). As
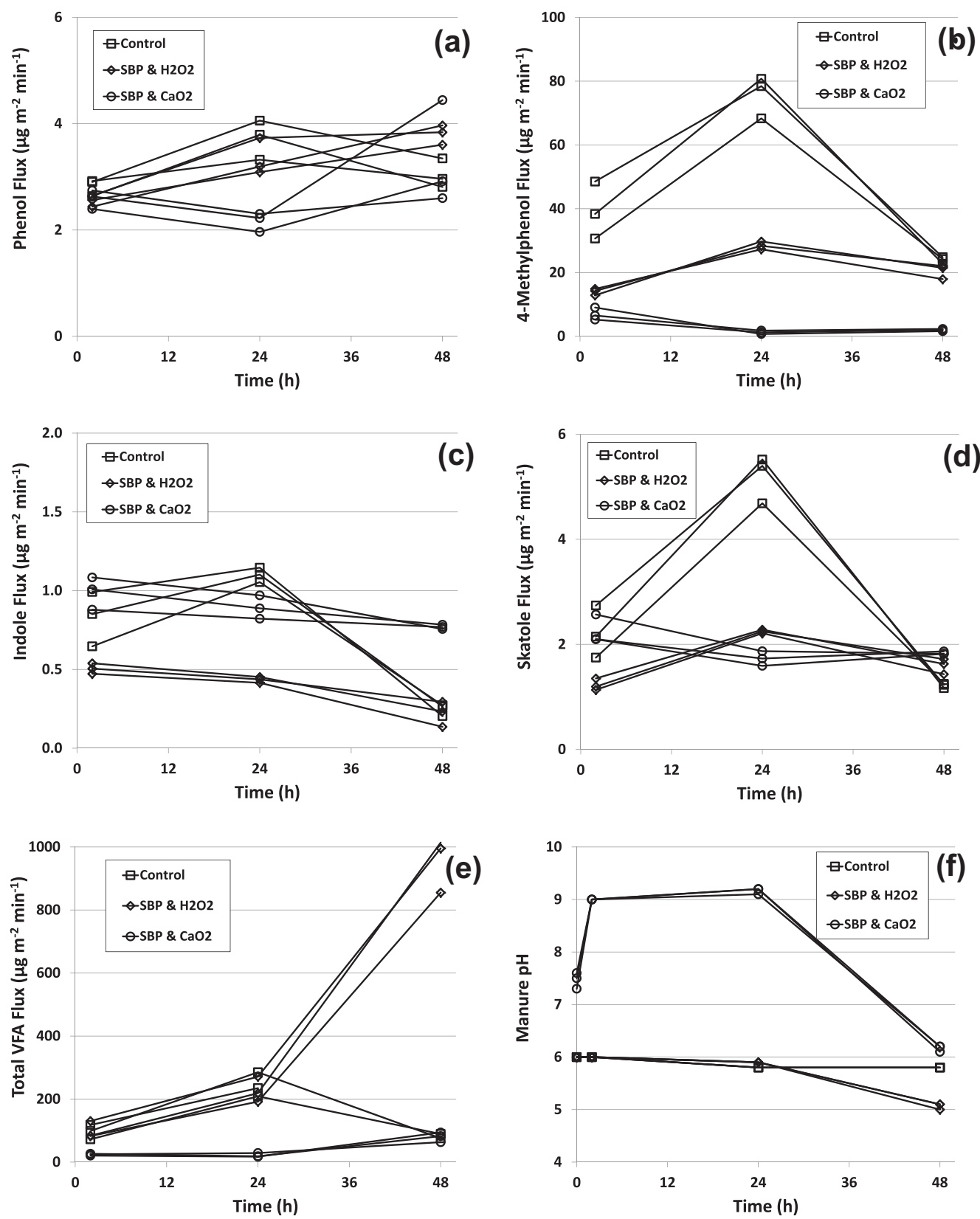

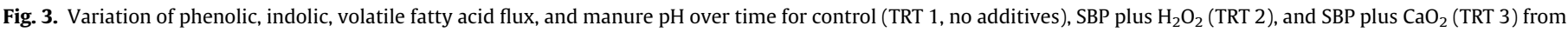
Experiment 5. 
an alternative explanation for the greatly increased VFAs observed (Table 4), the $\mathrm{H}_{2} \mathrm{O}_{2}$ could steer microbial fermentation end products from amino acid derived alcohols and aldehydes to the more oxidized acids (Hazelwood et al., 2008). These two possible explanations are fully compatible with one another.

When conducting the emission measurements the researchers observed considerable differences in odors between the control and treated manure samples. The control smelled like typical swine manure, yet the $\mathrm{SBP} / \mathrm{CaO}_{2}$ treated manure was described by the researchers as being considerably less offensive and having 'earthy' and 'grainy' character notes. One researcher described the $\mathrm{SBP} / \mathrm{CaO}_{2}$ treated manure as smelling like 'cooked oatmeal'. Significantly less microbial activity would be expected at $\mathrm{pH} 9$ than at pH 5.1-6.0 (Table 4).

\subsection{Effectiveness of 4-methylphenol reduction for odor control in swine manure}

While the SBPP treatments caused a considerable decrease in 4methylphenol emissions, the emissions of some other compounds (indole, skatole, and VFAs) were higher in some of the treated samples. As cases in point, the emissions of indole and skatole were higher in the SBP plus $\mathrm{CaO}_{2}$ treatment at $48 \mathrm{~h}$ (Fig. $3 \mathrm{c}$ and d) and the VFA emissions were about 10 -fold higher in the SBP plus $\mathrm{H}_{2} \mathrm{O}_{2}$ treatment at $48 \mathrm{~h}$ (Fig. 3e). Thus, the question still arises as to the relative importance of these increases in indole, skatole, and/or VFA emissions relative to the decrease in 4-methylphenol emissions. The odor activity value (OAV) analyses provided insight into the overall odor contributions of the different compounds.
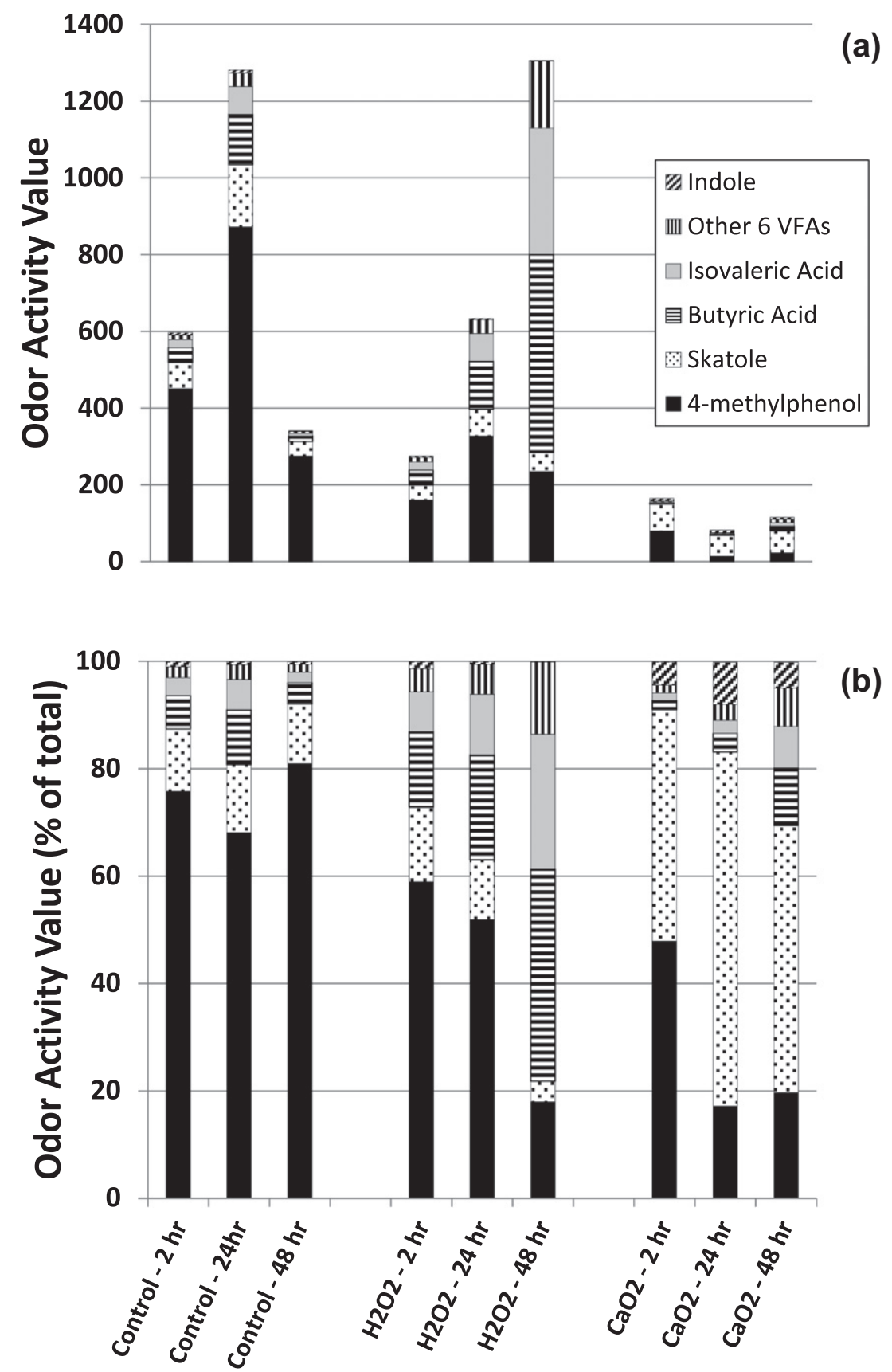

(b)

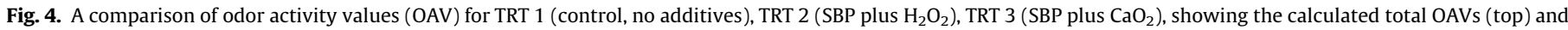
the relative OAV as a percentage of the summed OAVs of all compounds (bottom). 
The geometric mean odor thresholds of indole, skatole, and 4methylphenol were of similar magnitude, with values of 2.1, 0.48 , and $1.3 \mu \mathrm{g} \mathrm{m}^{-3}$, respectively (Parker et al., in press) and the odor threshold for the sum of eight VFAs was $869 \mu \mathrm{g} \mathrm{m}^{-3}$. As presented in Fig. 4, 4-methylphenol by itself accounted for $68-81 \%$ of the summed OAVs for the control. This OAV compares favorably to the $80 \%$ reported by Parker et al. (in press) for land-applied swine manure. Similarly, Feilberg et al. (2010) reported that 4-methylphenol had the highest concentrations above land applied swine manure slurry (175-300 ppb for 4-methylphenol compared to 0-30 ppb for other odorous compounds). Other compounds contributing considerably to the summed OAVs of the control were skatole (11-13\%), butyric acid (4-10\%), and isovaleric acid (2-6\%).

The OAV of the control at $2 \mathrm{~h}$ was 597, compared to 275 (54\% reduction) for the $\mathrm{H}_{2} \mathrm{O}_{2}$ treatment, and 165 ( $72 \%$ reduction) for the $\mathrm{CaO}_{2}$ treatment while after $48 \mathrm{~h}$, there was a $283 \%$ increase in OAV for the $\mathrm{H}_{2} \mathrm{O}_{2}$ treatment and a $66 \%$ reduction for $\mathrm{CaO}_{2}$. Note that even though there was a reduction in 4-methylphenol in the $\mathrm{H}_{2} \mathrm{O}_{2}$ treatment, the increase in VFA emissions caused an overall increase in OAV.

The actual increase in indole emission rate was $0.53 \mu \mathrm{g} \mathrm{m}^{-2} \mathrm{~min}^{-1}$ after $48 \mathrm{~h}$ (Fig. 3c) which equates to an increase in its contribution to OAV of 3.8 -fold. However, the decrease in 4methylphenol of $22.0 \mu \mathrm{g} \mathrm{m}^{-2} \mathrm{~min}^{-1}$ (Fig. 3b) equates to a decrease in OAV of 253-fold. Similarly, the increase in OAV for skatole due to its increase in flux of $0.62 \mu \mathrm{g} \mathrm{m}^{-2} \mathrm{~min}^{-1}$ (Fig. 3d) was 19.4 times, again much smaller than the 253-fold decrease in OAV for 4-methylphenol. Thus, the reduction in 4-methylphenol flux far outweighed the increased flux for indole and skatole in terms of odor emissions.

Finally, the odor threshold for the sum of eight VFAs of $869 \mathrm{\mu g} \mathrm{m}^{-3}$ equates to an approximate emission rate of $58 \mu \mathrm{g} \mathrm{m}^{-2} \mathrm{~min}^{-1}$. The actual increase in VFA emissions with the $\mathrm{H}_{2} \mathrm{O}_{2}$ treatment was about $873 \mu \mathrm{g} \mathrm{m}^{-2} \mathrm{~min}^{-1}$, for a 15 -fold increase in OAV. Again, compared to the 253-fold decrease in OAV for 4-methylphenol, the overall increase in odor for the VFAs was overshadowed by the greater decrease in OAV for 4-methylphenol.

\subsection{Safety and economics}

Soybean peroxidase is a fine organic powder, and it should be handled with the same precautions necessary for grain dust, which can be explosive if dispersed or suspended in air and ignited. Therefore, soybean peroxidase should be applied directly to the swine manure such that dispersion into the air is minimized. In addition, oxidizable materials such as calcium peroxide can be ignited by grinding (FMC, 2009). For this reason, calcium peroxide should always be added to the soybean peroxidase after the soybean hulls have been ground or otherwise processed.

A detailed economic analysis was deemed premature until further field experiments have been conducted. Nevertheless, the use of highly purified SBP such as that discussed in Hailu et al. (2010) appears to be uneconomical at this point. Hailu et al. (2010) reported a price of 7.5 USD per million units of enzyme activity for highly purified SBP. At this price, the cost to treat all of the manure from a single pig would exceed 100 USD, which is obviously uneconomical with today's pork prices.

\subsection{Opportunities for future research}

Despite the poor economics of purified SBP, the use of low purity, industrial grade SBP such as that used in this research, if only applied topically to the manure, would likely be more economical. Future studies are warranted to focus on the topical application of SBP to manure in larger pilot-scale laboratory containers, followed by field studies of SBP application in operating swine barns. In addition, polyethylene glycol (PEG) or other secondary additives as discussed in Wu et al. (1997) could possibly be used to improve treatment performance and economics.

\section{Conclusions}

For treating swine manure slurry, the optimum SBP application rate was $50 \mathrm{~g} \mathrm{~L}^{-1}$ when combined with $\mathrm{H}_{2} \mathrm{O}_{2}$ or $\mathrm{CaO}_{2}$ concentrations of 14.6 or $22.1 \mathrm{mM}$, respectively. The SBP plus $\mathrm{H}_{2} \mathrm{O}_{2}$ treatment resulted in a corresponding 10 -fold increase in VFA emissions. The SBP plus $\mathrm{CaO}_{2}$ treatment was most effective, decreasing the emission rates of the primary odorant 4-methylphenol by $98 \%$ and $92 \%$ after 24 and 48 h, respectively, with corresponding decreases in summed OAVs of $94 \%$ and $68 \%$. The overall results of our SBPP approach suggest that SBP plus $\mathrm{CaO}_{2}$ could be a promising treatment option for odor reduction from swine manure.

\section{Acknowledgements}

This research was funded by the USDA National Institute of Food and Agriculture (NIFA) Grant Award No. 2007-35112-21117 entitled "Abatement of Phenolic and Indolic VOC Emissions for Odor Control at Animal Feeding Operations." The 3rd author acknowledges the support made by the National Research Foundation of Korea (NRF) Grant funded by the Ministry of Education, Science and Technology (MEST) (No. 2009-0093848).

\section{References}

Akdeniz, N., Koziel, J.A., Ahn, H.-K., Glanville, T.D., Crawford, B.P., Raman, D.R., 2010. Laboratory scale evaluation of volatile organic compound emissions as indication of swine carcass degradation inside biosecure composting units. Bioresour. Technol. 101, 71-78.

Bratsch, A., 2009. Specialty crop profile: Horseradish. Virginia Cooperative Extension, Publication 438-104. Virginia Polytechnic Institute and State University, 10 pp. Available at: <http://pubs.ext.vt.edu/438/438-104/438104_pdf.pdf>.

CAQCC, 1999. Colorado Air Quality Control Commission Regulation No. 2, March 30 , 1999.

Caza, N., Bewtra, J.K., Biswas, N., Taylor, K.E., 1999. Removal of phenolic compounds from synthetic wastewater using soybean peroxidase. Water Resour. 33, 3012 3018.

Chen, L., Hoff, S.J., Koziel, J.A., Cai, L., Zelle, B., Sun, G., 2008. Performance evaluation of a wood-chip based biofilter using solid-phase microextraction and gas chromatography-mass spectroscopy-olfactometry. Bioresour. Technol. 99, 7767-7780.

Chen, Y., Bundy, D.S., Hoff, S., Steven, J., 1999. Using olfactometry to measure intensity and threshold dilution ratio for evaluating swine odor. J. Air Waste Manage. Assoc. 49 (7), 847-853.

Conn, K.L., Topp, E., Lazarovits, G., 2007. Factors influencing the concentration of volatile fatty acids, ammonia, and other nutrients in stored pig manure. J. Environ. Qual. 36, 440-447.

Donnell, C., Parker, D.B., Matlack, R.S., Caraway, E.A., Rhoades, M.B., Spears, J., 2008. Zeolite amendment to minimize ammonia, hydrogen sulfide, and VOC emissions. In Proc. Intl. Mtg. American Society of Agricultural and Biological Engineers, Providence, Rhode Island. Paper No. 084133, p. 6.

Feilberg, A., Dorno, N., Nyord, T., 2010. Odour emissions following land spreading of animal slurry assessed by proton-transfer-reaction mass spectrometry (PTRMS). Chem. Eng. Trans. 23, 111-116.

Flock, C., Bassi, A., Gijzen, M., 1999. Removal of aqueous phenol and 2-chlorophenol with purified soybean peroxidase and raw soybean hulls. J. Chem. Tech. Biotech. 74, 303-309.

FMC, 2009. Material Safety Data Sheet, Calcium Peroxide. FMC Corporation, CAS No. 1305-79-9, 10pp. Available at: <http://msdsviewer.fmc.com/>.

Gijzen, M., van Huystee, R., Buzzell, R.I., 1993. Soybean seed coat peroxidase: a comparison of high-activity and low-activity genotypes. Plant Physiol. 103, 1061-1066.

Govere, E.M., Tonegawa, M., Bruns, M.A., Wheeler, E.F., Kephart, K.B., Voigt, J.W., Dec, J., 2007. Using minced horseradish roots and peroxides for the deodorization of swine manure: a pilot scale study. Bioresour. Technol. 98, 1191-1198.

Guadagni, D.G., Buttery, R.G., Okano, S., Burr, H.K., 1963. Additive effect of subthreshold concentrations of some organic compounds associated with food aromas. Nature 200, 1288-1289.

Hailu, G., Weersink, A., Cahlik, F., 2010. Examining the prospects for commercialization of soybean peroxidase. AgBioForum 13, 263-273. 
Hawe, S.M., Walker, N., Moss, B.W., 1992. The effects of dietary fibre, lactose, and antibiotic on the levels of skatole and indole in feces and subcutaneous fat in growing pigs. Anim. Prod. 54, 413-419.

Hazelwood, L.A., Daran, J.-M., van Maris, A.J.A., Pronk, J.T., Dickinson, J.R., 2008. The Ehrlich pathway for fusel alcohol production: a century of research on Saccharomyces cerevisiae metabolism. Appl. Environ. Microbiol. 74, 2259-2266.

Kai, P., Schafer, A., 2004. Identification of key odour components in pig house air using hyphenated gas chromatography olfactrometry. CIGR J. Sci. Res. Dev. 6, 111.

Kim, K., Baek, S.O., Choi, Y., Sunwoo, Y., Jeon, E., Hong, J.H., 2006. The emissions of major aromatic VOC as landfill gas from urban landfill sites in Korea. Environ. Mon. Assess. 118, 407-422.

Leffingwell, J.C., Leffingwell, D., 1991. GRAS flavor chemicals - detection thresholds. Perfumer Flavorist 16, 2-19.

Macfarlane, J., Macfarlane, G.T., 1995. Proteolysis and amino acid fermentation. In: Gibson, G.R., Macfarlane, G.T. (Eds.), Human Colonic Bacteria. CRC Press, New York, pp. 75-100.

Mackie, R.I., Stroot, P.G., Varel, V.H., 1998. Biochemical identification and biological origin of key odor components in livestock waste. J. Anim. Sci. 76, 1331-1342.

Masuda, T., Goldsmith, P.D., 2009. World soybean production: area harvested, yield, and long-term projections. Int. Food Agrib. Manage. Rev. 12 (4), 143-161.

Mata-Alvarez, J., Mace, S., Llabres, P., 2000. Anaerobic digestion of organic solid wastes. An overview of research achievements and perspectives. Bioresour. Technol. 74, 3-16.

Miller, D.N., Berry, E.D., 2005. Cattle feedlot soil moisture and manure content: I. Impacts on greenhouse gases, odor compounds, nitrogen losses, and dust. J. Environ. Qual. 34, 644-655.

Miller, D.N., Varel, V.H., 2003. Swine manure composition affects the biochemical origins, composition, and accumulation of odorous compounds. J. Anim. Sci. 81, 2131-2138.
Morawski, B., Quan, S., Arnold, F.H., 2001. Functional expression and stabilization of horseradish peroxidase by directed evolution in Saccharomyces cerevisiae. Biotechnol. Bioeng. 76, 99-107.

Parker, D.B., Gilley, J., Woodbury, B., Kim, K.-H., Bartelt-Hunt, S., Li, X., Snow, D. Galvin, G., in press. Odorous VOC emission following land application of swine manure slurry. Atm. Environ. doi: http://dx.doi.org/10.1016/ j.atmosenv.2012.01.001.

Parker, D.B., 2007. Reduction of odor and VOC emissions from a dairy lagoon. Trans. ASABE 24, 647-655.

Redwine, J., Lacey, R., 2000. A summary of state odor regulations pertaining to confined animal feeding operations. In: Proc. Air Pollution from Agricultural Operations, American Society of Agricultural Engineers, St. Joseph, MI, pp. 3341.

Sweeten, J.M., 1995. Odor measurement technology and applications: a state-ofthe-art review. In: Ross, C.C. (Ed.), Seventh Int. Symp. Agric. and Food Processing Wastes, June 18-20 1995. American Society of Agricultural Engineers, St. Joseph, MI, pp. 214-229.

Tonegawa, M., Dec, J., Bollag, J.-M., 2003. Use of additives to enhance the removal of phenols from water treated with horseradish and hydrogen peroxide. J. Environ. Qual. 32, 1222-1227.

Veitch, N.C., 2004. Horseradish peroxidase: a modern view of a classic enzyme. Phytochemistry 65, 249-259.

Velthof, G.L., Nelemans, J.A., Oenema, O., Kuikman, P.J., 2005. Gaseous Nitrogen and carbon losses from pig manure derived from different diets. J. Environ. Qual. 34 698-706.

Wu, Y., Taylor, K.E., Biswas, N., Bewtra, J.K. 1997. Comparison of additives in the removal of phenolic compounds by peroxidase-catalyzed polymerization. Water Resour. 31, 2699-2704.

Ye, F.X., Zhu, R.F., Li, Y., 2009. Deodorization of swine manure slurry using horseradish and peroxides. J. Haz. Materials 167, 148-153. 